\title{
The effects of dietary supplementation of yeast culture on performance, blood parameters and immune system in broiler turkeys"
}

\author{
Bülent ÖZSOY ${ }^{1}$, Sakine YALÇIN ${ }^{2}$ \\ ${ }^{1}$ Mustafa Kemal University, Faculty of Veterinary Medicine, Department of Animal Nutrition and Nutritional Disease, Hatay, \\ Turkey. ${ }^{2}$ Ankara University, Faculty of Veterinary Medicine, Department of Animal Nutrition and Nutritional Disease, Ankara, \\ Turkey.
}

\begin{abstract}
Summary: This experiment was carried out to determine the effects of different levels of yeast culture (Saccharomyces cerevisiae) supplementation to the broiler turkey diets on the performance characteristics, some blood parameters and immune system. A total of 48 female poults aged five weeks were divided into one control group and three treatment groups each containing 12 female poults. The diets of the first, second and third treatment groups were supplemented with 1,2 and $3 \mathrm{~g} / \mathrm{kg}$ yeast culture (Diamond V "XP", Saccharomyces cerevisiae), respectively. The experimental period lasted 10 weeks. At the end of the experiment body weight, body weight gain, feed consumption, feed efficiency, carcass yield, weights and rates of internal organs, abdominal fat and the values of $\mathrm{pH}$ and viscosity of small intestine of turkeys were not significantly affected by different levels of yeast culture. There were no significant differences among the groups in total protein, cholesterol, triglyceride, uric acid, alanine aminotransferase, aspartate aminotransferase, alkaline phosphatase of blood serum and haemetological parameters. Immune system of turkeys was also not affected by dietary yeast culture. The results in this study demonstrated that yeast culture (Saccharomyces cerevisiae) supplementation at the levels of 1,2 and $3 \mathrm{~g} / \mathrm{kg}$ to the diets of female broiler turkeys did not have any significant effects on performance characteristics, some blood parameters and immune system.
\end{abstract}

Key words: Broiler turkey, blood parameters, immune system, performance, yeast culture

\section{Broyler hindi rasyonlarına maya kültürü ilavesinin performans, kan parametreleri ve bağışıklık sistemi üzerine etkileri}

Özet: $\mathrm{Bu}$ araştırma, broyler dişi hindi rasyonlarına farklı düzeylerde maya kültürü (Saccharomyces cerevisiae) ilavesinin hindilerde verim özellikleri, bazı kan parametreleri ve immun sistem üzerine etkilerini belirlemek amacıyla yapılmıştır. Toplam 48 adet 5 haftalık dişi palazı her biri 12 adet palazdan meydana gelen 1 kontrol ve 3 deneme olmak üzere toplam 4 gruba ayrılmıştır. Birinci, ikinci ve üçüncü deneme grupları rasyonlarına sırasıyla 1, 2 ve $3 \mathrm{~g} / \mathrm{kg}$ düzeylerinde maya kültürü (Diamond V "XP”, Saccharomyces cerevisiae) ilave edilmiştir. Deneme 10 hafta sürdürülmüştür. Araştırma sonunda rasyonlara farklı düzeylerde ilave edilen maya kültürünün hindilerde canlı ağırlık, canlı ağılık artışı, yem tüketimi ve yemden yararlanma oranı üzerine önemli etkisi gözlenmemiştir. Rasyonlara maya kültürü ilavesi karkas randımanını, iç organ ağırlıklarını, abdominal yağ ağırlı̆̆ ile oranlarını, ince bağırsak pH'sı ve viskositesini etkilememiştir. Kan serumu toplam protein, kolesterol, trigliserit, ürik asit ALT, AST, ALP düzeyleri bakımından gruplar arasında istatistik önem taşıyan farklılık oluşmamıştır. Hindilerde maya kültürünün immun sistem üzerinde de herhangi bir önemli etkisi olmadı̆̆ görülmüştür. Sonuç olarak, broyler dişi hindi rasyonlarına 1 , 2 ve $3 \mathrm{~g} / \mathrm{kg}$ düzeylerinde maya kültürü (Saccharomyces cerevisiae) ilavesinin hindilerde verim özellikleri, bazı kan parametreleri, ince bağırsak pH'sı ve viskositesi ile immun sistem üzerinde önemli bir etkisi saptanmamıştır.

Anahtar kelimeler: Etlik hindi, immun sistem, kan parametreleri, maya kültürü, performans

\section{Introduction}

Yeasts are important natural growth promoters. Saccharomyces cerevisiae, also known as "bakers yeast", is one of the most widely commercialized yeast species. Yeasts were the best source of protein, amino acid and vitamins B. Yeast contains protein which is equivalent approximately to soy-bean meal protein. The deficiency of lysine in diets can be completed with yeast.

There are some reports about the usage of yeast culture in poultry. Guevara et al. (1978) observed a trend toward decreased growth rate and feed utilization in broiler chicks as the dietary concentration of live yeast

\footnotetext{
${ }^{*}$ This research has been summarized from Ph.D. thesis.
} 
Table 1. Composition (\%) and nutrient contents of diets

Tablo 1. Karma yemlerin bileşimi (\%) ve besin maddesi içerikleri

\begin{tabular}{|c|c|c|c|c|c|}
\hline \multirow[b]{2}{*}{ Ingredient (\%) } & \multicolumn{5}{|c|}{ Weeks } \\
\hline & $6-7$ & $8-9$ & $10-11$ & $12-13$ & $14-15$ \\
\hline Corn & 41,15 & 46,50 & 51,00 & 55,70 & 57,50 \\
\hline Soybean meal & 34,00 & 29,70 & 22,1 & 14,00 & 8,50 \\
\hline Full-fat soya & 15,50 & 15,00 & 16,00 & 19,55 & 21,30 \\
\hline Meat and bone meal & 4,50 & 3,50 & 4,00 & 3,50 & 3,70 \\
\hline Sunflower seed oil & 1,40 & 2,20 & 3,80 & 4,25 & 6,20 \\
\hline Limestone & 1,20 & 1,10 & 1,10 & 1,10 & 1,00 \\
\hline Dicalcium phosphate & 1,25 & 1,15 & 1,15 & 1,15 & 1,10 \\
\hline Salt & 0,25 & 0,25 & 0,25 & 0,25 & 0,25 \\
\hline Vitamin premix $^{1}$ & 0,15 & 0,15 & 0,15 & 0,15 & 0,15 \\
\hline Mineral premix ${ }^{2}$ & 0,10 & 0,10 & 0,10 & 0,10 & 0,10 \\
\hline Methionine & 0,25 & 0,20 & 0,20 & 0,10 & 0,10 \\
\hline Lysine & 0,25 & 0,15 & 0,15 & 0,15 & 0,10 \\
\hline \multicolumn{6}{|l|}{ Chemical analyses } \\
\hline Metabolisable energy $(\mathrm{kcal} / \mathrm{kg})^{3}$ & 2948 & 3053 & 3202 & 3329 & 3483 \\
\hline Dry matter (\%) & 91,80 & 91,10 & 91,30 & 91,15 & 91,85 \\
\hline Crude protein (\%) & 25,95 & 23,90 & 21,80 & 19,50 & 17,90 \\
\hline Ether extract (\%) & 6,85 & 8,00 & 10,40 & 10,75 & 13,90 \\
\hline Crude fibre $(\%)$ & 2,58 & 2,68 & 2,60 & 2,88 & 2,44 \\
\hline $\mathrm{Ca}(\%)$ & 1,31 & 1,26 & 1,29 & 1,34 & 1,12 \\
\hline $\mathrm{P}(\%)$ & 0,88 & 0,65 & 0,67 & 0,67 & 0,66 \\
\hline
\end{tabular}

1 Provides per kg : 14000000 IU vitamin A, 4000000 IU vitamin D3, 80 g E vit, $30 \mathrm{~g}$ vitamin K, $33 \mathrm{~g}$ vitamin B1, $8 \mathrm{~g}$ vitamin B2, $40 \mathrm{~g}$ niacin, $12 \mathrm{~g}$ panthotenic acid,6 $\mathrm{g}$ vitamin B6 0,03 $\mathrm{g}$ vitamin B12, $2 \mathrm{~g}$ folic acit, $0,15 \mathrm{~g}$ biotin, $50 \mathrm{~g}$ vitamin C.

2 Provides per kg : $150 \mathrm{~g} \mathrm{Mn}, 120 \mathrm{~g} \mathrm{Fe}, 150 \mathrm{~g} \mathrm{Zn}, 14 \mathrm{~g} \mathrm{Cu}, 0,4 \mathrm{~g} \mathrm{Co}, 3 \mathrm{~g} \mathrm{I}, 0,3 \mathrm{~g} \mathrm{Se}$

3 Metabolizable energy content of diets estimated using the equation of Carpenter and Clegg (Leeson and Summers, 2001).

culture increased in the diet. Onifade and Babatunde (1996) indicated that the supplementation of dried yeast containing Saccharomyces cerevisiae as a pure culture to high fiber diets containing palm kernel meal significantly $(P<0.05)$ improved body weight gain, feed efficiency, and apparent retention coefficients of dry matter, crude protein, ether extract, crude fiber, and neutral detergent fiber in broiler chicks from 7 to $35 \mathrm{~d}$ of age. Gao et al. (2008) concluded that yeast culture improves growth performance and immune system. The effects of feeding yeast culture on the production and the effective level of supplementation in broiler turkeys are still controversial. Therefore the present study was conducted to evaluate the effects of different levels of yeast culture (Saccharomyces cerevisiae) supplementation to the diets on the performance characteristics, some blood parameters and immune system in female broiler turkeys.

\section{Materials and Methods}

A total of 48 female poults (Canadian white feather colour Hybrid Converter), five weeks old, were used in this study. Poults were divided into 4 equal groups (each group contained 12 poults) with one control group and three treatment groups. Each group was divided into four replicates comprising three poults each. They were housed in cages (170x94x90 cm; widthxlengthxheight) in a windowed house with a light regimen of 18L:6D. Temperature in house was maintained at $30^{\circ} \mathrm{C}$ for the first week and then gradually reduced according to the normal management practices, to a temperature of $20^{\circ} \mathrm{C}$.
Feed (in mash form) and water were provided ad libitum during the entire 10 weeks.

The ingredients and chemical composition of the basal diets are presented in Table 1. The diets were formulated to meet or exceed the nutrient requirements of poults of the management guide of Canadian white feather colour Hybrid Converter (Cold Spring Farm, 2000). Each basal diet was supplemented with 1, 2, 3 $\mathrm{g} / \mathrm{kg}$ commercial yeast culture product (Diamond V XP yeast culture supplied from Interchemie Chemistry Industry Import Export and Trading Corp., Ankara, Turkey). This was a fermented product composed of Saccharomyces cerevisiae grown on a medium of ground yellow corn, hominy feed, corn gluten feed, wheat middlings, rye middlings, diastatic malt, corn syrup and cane molasses and dried to preserve the fermenting activity of yeast. The analysis of yeast culture product was not less than $12.0 \%$ of crude protein, not less than $3.0 \%$ ether extract and not more than $6.5 \%$ crude fiber (DIAMOND, 2007).

Nutrient composition of basal diet was determined according to the AOAC (2000). The sample of diets was ashed in a muffle furnace prior to the analysis of calcium (Farese et al., 1967) and total phosphorus (ADAS, 1981). Metabolizable energy levels of diets were estimated using the equation of Carpenter and Clegg (Leeson and Summers, 2001):

ME, $\mathrm{kcal} / \mathrm{kg}=53+38[($ crude protein, $\%)+(2.25 \mathrm{x}$ ether extract, $\%)+(1.1 \times$ starch, $\%)+($ sugar, $\%)]$. 
Poults were weighed individually at the beginning of the experimental period and weekly to calculate body weight gain. Feed consumption was recorded weekly and feed efficiency was calculated as $\mathrm{kg}$ feed per $\mathrm{kg}$ body weight gain. Animals were followed up daily to determine mortality.

At the last of the trial all of the animals were individually weighed and 5 animals per group were randomly selected, weighed and slaughtered by severing the jugular vein, inert organs, head and foot were removed manually after defeathering. Hot carcass weights were determined and carcass yield was calculated. Absolute and proportional weights of abdominal fat, liver, heart, gizzard, spleen and kidney were also determined. The contents of small intestine were homogeneized in the tubes and the $\mathrm{pH}$ was measured with $\mathrm{pH}$ meter (Orion 420A). The homogenized intestinal contents were placed in microcentrifuge tubes, and then centrifuged at $12000 \mathrm{~g}$ for 10 minutes. The supernatant was withdrawn and the viscosity determined with viscometer (model LVDV-I, Brookfield Digital Viscometer) as cps (centipoise) (Graham et al., 1993).

At d 69, five animals from each group were randomly selected and bled from the brachial vein. Blood samples were taken in two tubes, one contained EDTA for estimating the haemetological parameters and the other had no anticoagulant for estimating blood serum parameters. Hemoglobine was determined with siyanid method by spectrophotometrically (Shimadzu digital spectrophotometer, HV-150 Kyoto, JAPAN) (Plaksi, 1972; Wells and Horn, 1965) and blood heamatocrit level was calculated using microheamatocrit method (Konuk, 1981). To determine serum parameters blood samples were centrifugated at $3000 \mathrm{~g}$ for 10 minutes. Then sera were harvested and stored at $-20{ }^{\circ} \mathrm{C}$ until analysis. Serum total protein, cholesterol, triglyceride, uric acid, alanin aminotransferase (ALT), aspartate amino transferase (AST) and alkaline phosphatase (ALP) were analyzed by Hitachi autoanalyser (Hitachi Ltd, Tokyo Seri No: 123823) using the commercial kits.

Immunization was determined by antibody against to New Castle Viruse. At the beginning of trial, blood samples were collected before vaccination. New Castle Vaccination was used at the eight week of trial. After twenty one day of vaccination blood samples were collected to measure antibody level by HemaglutinationInhibiton test (Arda, 1976).

Statistical anayses were done using SPSS programme (SPSS Inc., Chicago, IL, USA). The normality of data distribution was checked using the Kolmogorov-Smirnov test. One-way ANOVA was performed to examine differences among groups. The significance of mean differences between groups were tested by Duncan. Values were given as mean \pm standard error. Level of significance was taken as $\mathrm{P}<0.05$ (Dawson and Trapp, 2001).

\section{Results}

Dietary supplementation of yeast culture had no significant effect on body weight (Table 2), body weight gain, feed intake and feed efficiency (Table 3). There were no treatment effects on carcass yield and the percentages of heart, liver, gizzard, spleen, kidney and abdominal fat weights (Table 4). Dietary treatments did not significantly affect blood parameters (Table 5), $\mathrm{pH}$ and viscosity of small intestinal content and anti-NDV titers (Table 6). No mortality was seen during the experiment.

Table 2. The body weights of groups (mean \pm standart error) Tablo 2. Grupların ağırlıkları (g) (ortalama \pm standart hata)

\begin{tabular}{ccccc}
\hline & Control & \multicolumn{3}{c}{ Experimental groups } \\
\cline { 3 - 5 } Weeks & group & 1 & 2 & 3 \\
\hline $\begin{array}{c}\text { Start of } \\
\text { trial } \\
\text { (5. wk) }\end{array}$ & $1232 \pm 25$ & $1242 \pm 24$ & $1263 \pm 26$ & $1250 \pm 23$ \\
6 & & & & \\
7 & $2519 \pm 57$ & $2540 \pm 51$ & $2574 \pm 68$ & $2615 \pm 53$ \\
8 & $3270 \pm 61$ & $3298 \pm 72$ & $3330 \pm 82$ & $3399 \pm 84$ \\
9 & $4067 \pm 78$ & $4087 \pm 94$ & $4151 \pm 92$ & $4276 \pm 96$ \\
10 & $4844 \pm 93$ & $4903 \pm 105$ & $4955 \pm 126$ & $5089 \pm 121$ \\
11 & $5586 \pm 103$ & $5682 \pm 129$ & $5784 \pm 135$ & $5876 \pm 138$ \\
12 & $6350 \pm 133$ & $6359 \pm 162$ & $6561 \pm 147$ & $6638 \pm 160$ \\
13 & $7135 \pm 150$ & $7075 \pm 178$ & $7361 \pm 148$ & $7435 \pm 159$ \\
14 & $7835 \pm 153$ & $7842 \pm 189$ & $8126 \pm 161$ & $8254 \pm 161$ \\
15 & $8392 \pm 159$ & $8501 \pm 194$ & $8742 \pm 177$ & $8948 \pm 172$ \\
\hline
\end{tabular}

$\mathrm{n}=12$ per group

No significant differences $(\mathrm{P}>0.05)$ among groups.

\section{Discussion and Conclusion}

The values for body weight (Table 2), body weight gain, feed intake and feed efficiency (Table 3) of broiler turkeys were not significantly affected from dietary yeast culture supplementation. Yeast culture at the level of 1,2 and $3 \mathrm{~g} / \mathrm{kg}$ increased total body weight gain 1,40\%, 4,47\% and $7,52 \%$, respectively compared to the control group. However this improvement in body weight gain was not statistically significant $(\mathrm{P}>0.05)$. Similar to the results of the present study yeast culture supplementation had no effect on body weight gain, feed intake and feed efficiency of poults (Bradley and Savage, 1995), broilers (Kahraman et al., 1999; Karaoğlu and Durdağ, 2005) and broiler breeders (Brake, 1991). Yalçın et al. (2008) reported that yeast culture (Saccharomyces cerevisiae, Diamond $\mathrm{V}$ XP) supplementation at the level of $2 \mathrm{~g} / \mathrm{kg}$ increased body weight gain and did not significantly affect feed intake and feed efficiency in laying hens. Onifade and Babatunde (1996) reported that supplementation of dried yeast (Saccharomyces cerevisiae) to the high fibre diets improved body weight gain of broiler chicks, feed efficiency was also improved in broilers fed 0.15 and $0.45 \%$ of dried yeast $(\mathrm{P}<0.05)$. Gao et al. (2008) observed that dietary supplemental yeast culture at $0.25 \%$ improved average daily gain and feed efficiency during 
Table 3. The effects of dietary yeast culture supplementation on body weight gain, feed intake and feed efficiency of turkeys (mean \pm standard error)

Tablo 3. Rasyonlara maya kültürü ilavesinin hindilerde ağırlık artışı, yem tüketimi ve yemden yararlanma oranı üzerine etkileri (ortalama \pm standart hata)

\begin{tabular}{|c|c|c|c|c|c|}
\hline \multirow[b]{2}{*}{ Weeks } & \multirow[b]{2}{*}{ Control } & \multicolumn{3}{|c|}{ Experimental groups } & \multirow[b]{2}{*}{$\mathrm{P}$} \\
\hline & & 1 & 2 & 3 & \\
\hline \multicolumn{6}{|c|}{ Body weight gain, $g$} \\
\hline $1-2$ & $1286 \pm 16$ & $1298 \pm 33$ & $1311 \pm 19$ & $1364 \pm 52$ & 0,40 \\
\hline $3-4$ & $1548 \pm 13$ & $1547 \pm 45$ & $1577 \pm 33$ & $1662 \pm 56$ & 0,20 \\
\hline $5-6$ & $1520 \pm 48$ & $1595 \pm 33$ & $1634 \pm 93$ & $1600 \pm 78$ & 0,68 \\
\hline $7-8$ & $1549 \pm 70 \mathrm{a}$ & $1393 \pm 44 b$ & $1577 \pm 50 \mathrm{a}$ & $1558 \pm 66 \mathrm{a}$ & 0,06 \\
\hline $9-10$ & $1257 \pm 42 b$ & $1426 \pm 38 \mathrm{a}$ & $1381 \pm 28 \mathrm{ab}$ & $1513 \pm 56 \mathrm{a}$ & 0,01 \\
\hline Total & $7159 \pm 100$ & $7259 \pm 91$ & $7479 \pm 191$ & $7697 \pm 225$ & 0,10 \\
\hline \multicolumn{6}{|c|}{ Feed intake, $\mathrm{g}$} \\
\hline $1-2$ & $2162 \pm 23$ & $2148 \pm 49$ & $2201 \pm 24$ & $2252 \pm 49$ & 0,22 \\
\hline $3-4$ & $3206 \pm 23$ & $3158 \pm 76$ & $3278 \pm 43$ & $3297 \pm 83$ & 0,39 \\
\hline $5-6$ & $3975 \pm 138$ & $3968 \pm 124$ & $4037 \pm 234$ & $4004 \pm 176$ & 0,99 \\
\hline $7-8$ & $4550 \pm 31$ & $4088 \pm 148$ & $4537 \pm 125$ & $4370 \pm 160$ & 0,08 \\
\hline $9-10$ & $4850 \pm 215$ & $5201 \pm 101$ & $5036 \pm 96$ & $5375 \pm 196$ & 0,18 \\
\hline Total & $18744 \pm 243$ & $18566 \pm 303$ & $19090 \pm 390$ & $19300 \pm 357$ & 0,42 \\
\hline \multicolumn{6}{|c|}{ Feed efficiency (kg feed / kg body weight gain) } \\
\hline $1-2$ & $1,68 \pm 0,03$ & $1,66 \pm 0,02$ & $1,68 \pm 0,01$ & $1,65 \pm 0,03$ & 0,80 \\
\hline $3-4$ & $2,07 \pm 0,01$ & $2,04 \pm 0,03$ & $2,08 \pm 0,05$ & $1,98 \pm 0,03$ & 0,22 \\
\hline $5-6$ & $2,62 \pm 0,11$ & $2,48 \pm 0,03$ & $2,47 \pm 0,06$ & $2,50 \pm 0,01$ & 0,42 \\
\hline $7-8$ & $2,94 \pm 0,01$ & $2,94 \pm 0,1$ & $2,88 \pm 0,07$ & $2,81 \pm 0,11$ & 0,70 \\
\hline $9-10$ & $3,85 \pm 0,04 \mathrm{a}$ & $3,65 \pm 0,04 \mathrm{~b}$ & $3,65 \pm 0,08 \mathrm{~b}$ & $3,55 \pm 0,02 b$ & 0,01 \\
\hline Total & $2,62 \pm 0,02$ & $2,56 \pm 0,01$ & $2,55 \pm 0,05$ & $2,51 \pm 0,04$ & 0,18 \\
\hline
\end{tabular}

$\mathrm{n}=4$ per group

a,b: means within a row followed by the same superscript are not significantly different $(\mathrm{P}>0.05)$.

Table 4. The effects of dietary yeast culture supplementation on carcass weight. carcass yield, internal organ weights and percentages in turkeys (mean \pm standard error)

Tablo 4. Rasyonlara maya kültürü ilavesinin hindilerde karkas ağırlığı, karkas randımanı. iç organ ağırlıkları ve oranları üzerine etkileri (ortalama \pm standart hata)

\begin{tabular}{lcccc}
\hline & & \multicolumn{3}{c}{ Experimental groups } \\
\cline { 3 - 4 } & Control group & 1 & 2 & 3 \\
\hline Slaughter weight, kg & $8319 \pm 173$ & $8208 \pm 156$ & $8326 \pm 78$ & $8670 \pm 166$ \\
Carcass weight, kg & $6700 \pm 157$ & $6623 \pm 124$ & $6658 \pm 117$ & $7094 \pm 136$ \\
Carcass yield, \% & $80,53 \pm 0,58$ & $80,70 \pm 0,25$ & $79,95 \pm 0,92$ & $81,82 \pm 0,83$ \\
Abdominal fat, g & $191,9 \pm 28,8$ & $187,8 \pm 10,9$ & $204,9 \pm 13$ & $202,6 \pm 4,1$ \\
Abdominal fat yield, g/100 g BW & $2,09 \pm 0,49$ & $2,29 \pm 0,15$ & $2,74 \pm 0,31$ & $2,34 \pm 0,05$ \\
Liver weight, g & $82,26 \pm 3,09$ & $82,28 \pm 2,62$ & $81,13 \pm 4,09$ & $86,61 \pm 0,89$ \\
Liver yield, g/100 g BW & $0,98 \pm 0,029$ & $1,01 \pm 0,041$ & $0,97 \pm 0,052$ & $1,00 \pm 0,016$ \\
Gizzard weight, g & $91,93 \pm 7,27$ & $84,58 \pm 2,05$ & $87,26 \pm 1,49$ & $95,04 \pm 3,27$ \\
Gizzard yield, g/100 g BW & $1,10 \pm 0,081$ & $1,03 \pm 0,028$ & $1,05 \pm 0,014$ & $1,09 \pm 0,031$ \\
Heart weight, g & $29,01 \pm 1,15$ & $28,41 \pm 0,93$ & $31,83 \pm 0,81$ & $30,24 \pm 1,39$ \\
Heart yield, g/100 g BW & $0,35 \pm 0,011$ & $0,35 \pm 0,15$ & $0,38 \pm 0,011$ & $0,35 \pm 0,017$ \\
Spleen weight, g & $6,87 \pm 0,53$ & $5,87 \pm 0,45$ & $6,78 \pm 0,27$ & $7,04 \pm 0,25$ \\
Spleen yield, g/100 g BW & $0,082 \pm 0,006$ & $0,072 \pm 0,006$ & $0,081 \pm 0,003$ & $0,081 \pm 0,003$ \\
\hline
\end{tabular}

$\mathrm{n}=5$ per group

No significant differences $(\mathrm{P}>0.05)$ among groups. 
Table 5. Some biochemical blood parameters in the groups (mean \pm standart error)

Tablo 5. Grupların bazı biyokimyasal kan parametreleri (ortalama \pm standart hata)

\begin{tabular}{lcccc}
\hline & Control & \multicolumn{3}{c}{ Experimental groups } \\
\cline { 2 - 4 } & group & 1 & 2 & 3 \\
\hline Total protein, g/dl & $3,22 \pm 0,06$ & $3,40 \pm 0,089$ & $3,24 \pm 0,093$ & $3,30 \pm 0,084$ \\
Cholesterol, mg/dl & $117,0 \pm 5,4$ & $121,2 \pm 5,3$ & $104,8 \pm 6,4$ & $111,2 \pm 3,6$ \\
Triglyceride, mg/dl & $122,8 \pm 14,0$ & $135,20 \pm 17,54$ & $98,20 \pm 10,11$ & $106,60 \pm 17,66$ \\
Uric acid mg/dl & $3,32 \pm 0,13$ & $3,14 \pm 0,23$ & $3,24 \pm 0,20$ & $2,96 \pm 0,40$ \\
ALT, U/I & $4,20 \pm 0,74$ & $4,20 \pm 0,66$ & $4,00 \pm 0,55$ & $4,20 \pm 0,49$ \\
AST, U/I & $390,8 \pm 15,1$ & $363,0 \pm 20,8$ & $362,6 \pm 29,9$ & $343,6 \pm 6,0$ \\
ALP, U/I & $1068 \pm 90$ & $1056 \pm 42$ & $1045 \pm 80$ & $1003 \pm 35$ \\
Haematocrit, \% & $35,80 \pm 1,11$ & $35,60 \pm 1,78$ & $34,00 \pm 089$ & $34,00 \pm 0,45$ \\
Haemoglobin, g/dl & $10,98 \pm 0,94$ & $12,01 \pm 1,22$ & $12,29 \pm 1,08$ & $10,85 \pm 0,47$ \\
\hline
\end{tabular}

$\mathrm{n}=5$ per group $\quad$ No significant differences $(\mathrm{P}>0.05)$ among groups.

Table 6. The intestinal $\mathrm{pH}$ and viscosity values and the antibody titer $\left(\log _{2}\right)$ against to Newcastle vaccination of groups

Tablo 6. Grupların ince bağırsak pH ve viskosite değerleri ile Newcastle hastalığı virusuna karşı oluşan ortalama $\log _{2}$ antikor titre değerleri (ortalama \pm standart hata)

\begin{tabular}{lccccc}
\hline & & Control & \multicolumn{3}{c}{ Experimental groups } \\
\cline { 3 - 6 } & $\mathrm{n}$ & group & 1 & 2 & 3 \\
\hline $\mathrm{pH}$ & 5 & $5,94 \pm 0,06$ & $5,94 \pm 0,05$ & $5,95 \pm 0,06$ & $6,09 \pm 0,63$ \\
Viscosity & 4 & $1,90 \pm 0,08$ & $2,21 \pm 0,23$ & $2,33 \pm 0,20$ & $1,77 \pm 0,46$ \\
Antibody titer & 5 & $8,80 \pm 0,86$ & $10,80 \pm 0,49$ & $11,80 \pm 0,37$ & $9,40 \pm 1,69$ \\
\hline
\end{tabular}

No significant differences $(\mathrm{P}>0.05)$ among groups.

grower and overall periods in broilers $(\mathrm{P} \leq 0.05)$. Some researchers reported that yeast culture have beneficial effects on broiler performance when broilers were challenged with Eimeria spp. (Stanley et al., 2004a) or consumed aflatoxin diet (Stanley et al., 2004b). The results of nonsignificant effect in performance in the present study may be explained that broiler turkeys were maintained in good experimental conditions and little environmental stress. Mortality was not seen in this study. Similarly, some researchers observed that no difference in mortality among groups fed diets supplemented with yeast culture in broilers (Gao et al., 2008) and laying hens (Yalçın et al., 2008). However, in the study of Tangendjaja and Yoon $(2002)$ mortality was reduced $(\mathrm{P}<0.05)$ by the yeast culture supplementation in laying hens.

Carcass weight, carcass yield and the percentages of liver, gizzard, heart, spleen and abdominal fat were not affected by dietary yeast culture (Table 4). Similarly, yeast culture supplementation had no effect on the carcass yield of turkeys (Savage et al, 1985) and broilers (Kahraman et al. 1999; Karaoğlu and Durdağ, 2005). However, Onifade et al. (1999b) reported that yeast culture supplementation increased carcass weight and carcass yield compared to control group $(\mathrm{P}<0,01)$. Savage et al. (1985) concluded that live yeast culture supplementation reduced the fat content of female turkeys. In agreement with our findings, Karaoğlu and Durdağ (2005) observed that probiotic (Saccharomyces cerevisiae, 115Biogallinox) supplementation had no effect on the percentages of liver, heart and gizzard in broilers.
Dietary yeast supplementation did not significantly affect blood parameters (Table 5). Similar results were also obtained by Yalçın et al. (2008) in serum levels of total protein, triglyceride, cholesterol, ALT, AST and ALP. Saoud and Daghir (1980) also observed that single cell protein had no effect on serum uric acid in broilers. However, Yalçın et al. (2008) observed that serum uric acid was increased $(P<0.05)$ by dietary yeast culture supplementation. Onifade et al. (1999a) reported that serum protein level was decreased and the serum levels of cholesterol, ALT, AST and ALP were increased with dietary yeast culture in rabbits. Onifade et al. (1999a) also concluded that rabbits fed $0.3 \%$ yeast culture had improved $(\mathrm{P}<0.05)$ haematological indices, namely haematocrit and haemoglobin compared to control group.

It was observed in the present study that there were no significant differences in $\mathrm{pH}$ and viscosity of small intestinal content (Table 6). Similarly intestinal $\mathrm{pH}$ in broilers (Kahraman et al., 1999), viscosity of small intestinal content in broilers (Owens and McCrachen (2003) and in rabbits (Kermauner and Struklec, 1999) were not affected by dietary yeast supplementation.

Dietary treatments did not significantly affect antiNDV titers (Table 6). However, Gao et al. (2008) reported that antibody titers to NDV increased linearly $(\mathrm{P}<0.05)$ when the level of dietary yeast culture increased which suggests that yeast culture may also influence systemic or humoral immunity of broilers.

Yeast culture contains yeast cells and metabolites such as peptides, organic acids, oligosaccharides, 
aminoacids, flavor and aroma substances to improve performance in animals. However no improvement in performance was obtained by yeast culture supplementation in broiler turkeys. Differences in animal responses in literatures may be related to differences in the dose and type of yeast culture, quality of diets, age of animal and experimental conditions.

In conclusion yeast culture (Saccharomyces cerevisiae) supplementation at the levels of 1,2 and 3 $\mathrm{g} / \mathrm{kg}$ to the diets of female broiler turkeys did not have any significant effects on performance characteristics, some blood parameters, small intestine $\mathrm{pH}$ and viscosity values and immune system.

\section{Acknowledgements}

We are thankful to Bolca Hindi for poult supply.

\section{References}

1. ADAS (1981): The Analysis of Agricultural Materials, Agricultural Development and Advisory Service, Ministry of Agriculture, Fisheries and Food, 2nd edn, Her Majesty's Stationery Office, London.

2. AOAC (2000): Official Methods of Analysis. Association of Official Analytical Chemists, 17th edn. AOAC International, Maryland.

3. Arda M (1976): Hollanda'da Newcastle hastalı̆̆ üzerinde araştırmalar ve HI testinin yeni yönteme göre değerlendirilmesi. Vet Hekim Der Derg, 46, 19-28.

4. Bradley GL, Savage TF (1995): Effect of pre-incubation egg storage time and genotype on hatchability of eggs from turkey breeder hens fed a diet containing a yeast culture. Poult Sci, Suppl, 72, 1- 44.

5. Brake J (1991): Lack of effect of alive yeast culture on broiler breeder and progeny performance. Poult Sci, 70, 1037-1039.

6. Cold Spring Farm (2000): Turkey Growing Manual. Cold Springs Farm Limited Ontario, Canada.

7. Dawson B, Trapp RG (2001): Basic and Clinical Bioistatistics. 3rd edn. Lange Medical Books/McGnawHill Medical Publishing Division, New York.

8. DIAMOND V (2007): Product Profiles. Ref 1004 03/04. Cedar http://www.diamondV.com Accessed Feb. 2007.

9. Farese G, Schmidt JL, Mager M (1967): An automated method for the determination of serum calcium with glyoxal bis (2-hydroxyanil). Clinical Chem, 13, 515-520.

10. Gao J, Zhang HJ. Yu SH, Wu SG, Yoon I, Quigley J, Gao YP, Qi GH (2008): Effects of yeast culture in broiler diets on performance and immunomodulatory functions. Poult Sci, 87, 1377-1384.

11. Graham H, Bedford M, Choct M (1993): High gut viscosity can reduce poultry performance. Feedsuffs and Poultry International, 65, 14-15.

12. Guevara VRB, Dilworth C, Day EJ (1978): Phosphorus utilization by broilers as affected by yeast culture. Poult Sci, 57, 1102-1103

13. Kahraman R, Abaş İ, Bostan K, Tanör MA, Kocabağlı N, Alp M (1999): Effects of organic acids and yeast culture on performance ileum $\mathrm{pH}$ and Enterobacteriaceae population of broilers. VIV Poultry Yutav'99 Istanbul 515-522.

14. Karaoğlu M, Durdağ H (2005): The influence of dietary probiotic (Saccharomyces cerevisiae) supplementation and different slaughter age on the performance, slaugter and carcass properties of broilers. Int J Poult Sci, 4, 309-316.

15. Kermauner A, Struklec M (1999): Effect of some probiotics on intestinal viscosity in rabbits. Acta Agraria Kaposvariensis, 3, 165-173.

16. Konuk T (1981): Pratik Fizyoloji I.,2. Bask1, Ankara Üniversitesi Veteriner Fakültesi Yayınları 378, Ders kitabı: 276, Ankara Üniversitesi Basımevi, Ankara.

17. Leeson S, Summers JD (2001): Nutrition of the Chicken. University Books, Guelph, Canada.

18. Onifade AA, Babatunde GM (1996): Supplemental value of dried yeast in a high-fibre diet for broiler chicks. Anim Feed Sci Technol, 62, 91-96.

19. Onifade AA, Obiyan RI, Onipede E, Adejumo DO, Abu OA, Babatunde GM (1999a): Assessment of the effects of supplementig rabbit diets with a culture of Saccharomyces cerevisiae using growth performance, blood composition and clinical enzyme activities. Anim Feed Sci Technol, 77, 25-32.

20. Onifade AA, Odunsi, AA, Babatunde GM, Olerede BR, Muma E (1999b): Comparison of the supplemental effect of Saccharomyces cerevisiae and antibiotic in low-protein and high-fibre diets fed to broiler chickens. Arch Anim Nutr, 52, 29-39.

21. Owens B, Mcrachen KJ (2003): Comparision of the effect of the addition of different yeast products and antibiotic to the diet broilers. 2003 Spring Meeting of The UK.

22. Plaksi S (1972): Vergleichende untersuchungen über den hamoglobingehalt des hühner und putenblutes in abhangigkeit von alter und geschlecht. Arc für Geflügelk, 36, 70-77.

23. Saoud NB, Daghir NJ (1980): Blood constituents of yeast fed chicks. Poult Sci, 59, 1807-1811.

24. Savage TF, Nakaue HS, Holmes ZA (1985): Effects of feeding a live yeast culture on market turkey performance and cooked meat characteristics. Nutr Rep Int, 3, 695-703

25. Stanley VG, Gray C, Daley M, Krueger WF, Sefton AE (2004a): An alternative to antibiotic-based drugs in feed for enhancing performance of broilers grown on Eimeria spp.-infected litter. Poult Sci, 83, 39-44

26. Stanley VG, Winsman M, Dunkley C, Ogunleye T, Daley M, Krueger WF, Sefton AE, Hinton AJR (2004b): The impact of yeast culture residue on the suppression of dietary aflatoxin on the performance of broiler breeder hens. J Appl Poult Res, 13, 533-539.

27. Tangendjaja B, Yoon I (2002): Effect of yeast culture on egg production and mortality in layer chickens. Page 89 in Poultry Science Association 91st Annual Meeting Abstracts. August 11-14, 2002. Newark, DE. Abstract No:380.

28. Wells A, Horn V (1965): Beitrag zur HamoglobinBestimmung in blut des geflügels. J Vet Med A, 12, 663-669.

29. Yalçın S, Özsoy B, Erol H, Yalçın S (2008): Yeast culture supplementation to laying hen diets containing soybean meal or sunflower seed meal and its effect on performance. J Appl Poult Res, 17, 229-236.

Geliş tarihi: 18.12.2009 / Kabul tarihi: 25.06.2010

Corresponding author:

Dr. Bülent Özsoy

Mustafa Kemal University

Faculty of Veterinary Medicine

Department of Animal Nutrition and Nutritional Disease

31040 Antakya/HATAY

e-mail:bulent58@gmail.com 